University for Business and Technology in Kosovo

UBT Knowledge Center

UBT International Conference

2016 UBT International Conference

Oct 28th, 9:00 AM - Oct 30th, 5:00 PM

\title{
From Asclepius to Ospedale - The evolution of space for healing from antiquity to the Age of Enlightenment
}

\author{
Nuran Saliu \\ State University of Tetova \\ Andrea Maliqari \\ Polytechnic University of Tirana \\ Kujtim Elezi \\ State University of Tetova \\ Ulvie Memedi Usejni \\ State University of Tetova
}

Follow this and additional works at: https://knowledgecenter.ubt-uni.net/conference

Part of the Architecture Commons

\section{Recommended Citation}

Saliu, Nuran; Maliqari, Andrea; Elezi, Kujtim; and Usejni, Ulvie Memedi, "From Asclepius to Ospedale - The evolution of space for healing from antiquity to the Age of Enlightenment" (2016). UBT International Conference. 74.

https://knowledgecenter.ubt-uni.net/conference/2016/all-events/74

This Event is brought to you for free and open access by the Publication and Journals at UBT Knowledge Center. It has been accepted for inclusion in UBT International Conference by an authorized administrator of UBT Knowledge Center. For more information, please contact knowledge.center@ubt-uni.net. 


\title{
FROM ASCLEPIUS TO OSPEDALE - THE EVOLUTION OF SPACE FOR HEALING FROM ANTIQUITY TO THE AGE OF ENLIGHTENMENT
}

\author{
Nuran Saliu ${ }^{1}$, Andrea Maliqari ${ }^{2}$, Kujtim Elezi ${ }^{1}$, \\ Ulvie Memedi-Usejni ${ }^{1}$ \\ ${ }^{1}$ State University of Tetova, Faculty of Applied Sciences \\ ${ }^{2}$ Polytechnic University of Tirana, Faculty of Architecture and Urban Planning
}

\begin{abstract}
In the construction industry, where in recent times every detail is looked over and planned with the most scientific and technological responsibility, hospitals represent the most investigated and scrutinized facilities.

Related closely with institutional and medical practices, hospital design has undergone many reconfigurations. The second half of the past century experienced and produced many hospital models (L, H, T, K type, Patients Tower, Block Plan, etc.), all with the same denominator - too big, isolated and highly complex structures, strictly opposed to nature, oriented towards medical technology rather than patient's well-being.

By the end of the twentieth century, a group of researchers arose in supporting the importance of 'nature' in the healthcare structures. The paradigm is changing. New models and configurations are emerging with the intent of improving the psycho-emotional well-being and social development of the patients who spend long time period of time in hospitals. The hospital design is moving towards patient-oriented solutions and healing environments, a model not invented in our time but inspired from history.

In this paper, through travels in history, we analyze the concept of hospital from the very beginning of rational thinking in Ancient Greece up to the Age of Enlightenment, with the intent to identify the forerunners of contemporary hospitals by means of cultural, medical and composition aspects. The geometrical properties of each facilities are also presented.
\end{abstract}

Keywords: Hospital design, history, geometry, composition, analysis.

\section{Introduction}

Each hospital is organized in accord with official sets of rules and functions as a specific environment, shaped by its location, architectural design, size and financial base (Risse, 1999). This statement summarizes the way in which all hospitals evolved.

Medicine and hospital design as it stands in our days, was not developed overnight, but rather it is a cumulative effort of thousands of people and medical scholars of different civilizations. Transition of knowledge between declining and rising civilization was a key factor of the progress and development. Similarly, the architectural concept of hospitals has undergone many transitional mutations. Sometimes linked with worship and rites, sometimes religious and sometimes scientific, hospitals evolved from simple building attached to the temples to complex massive self-included buildings, typical of the modern times.

Even today, new efforts of paradigm shift in recent developments of hospital design - the very concept of seeing a hospital not as medical and technological bulk but rather a patient oriented 
structure - can be seen as knowledge transition. Flexibility, adaptability, standardization and the importance of the patient and his environment are the guiding principles of the new hospitals, i.e. hospital is starting to lose its technological image and emphasizes the patient as dominant force.

Illness can be understood as a process in which a changing point of view is experienced and cure as the process of relieve of such condition. Relieving a sick man from pain is as old as human history. The very act of carrying for someone in someplace constructs a space for healing. When this place is organized and structured for the first time in accord with sets of rules and functions of a certain society is a matter of debate. Although, the evolution of organized spaces for healing can be traced back to ancient Mesopotamia, India, China and South East Asia, in this paper we start with the Ancient Greece based on the simple argument that medical rational thinking originated there.

Our focus on historical evolution of healthcare spaces is oriented within the context of three basic principles that contribute in designing a hospital even in our times: cultural, medical and architectural features. For a better understandability, this paper overviews hospital evolution according to a division of three main temporal frames: Antiquity - starting from Ancient Greece (although the evolution of hospitals can be traced in ancient Mesopotamia), continuing with the Roman Empire and the dawn of Christianity; Medieval Ages - continuing with Christianity and then exploring "the Golden Age" of Islam; to end with Renaissance and the beginning of the Age of Reason Enlightenment.

\section{Antiquity}

\subsection{Greek Asclepieons}

Although the ancient Greeks are recognized as the founders of rational medicine - based on the Hippocrat's separation between medicine and religion and his beliefs that diseases were caused naturally and not from superstitions and gods - their practices of healing did not converge with this 'rationale' thinking. Greek medicine was not a solid structure of knowledge and practices but rather a mix of methods and different practices dependent on local traditions and religious cults. Their religion and cults, constituted a key social ordering principle concerned with daily basic existential needs (Risse, 1999). Hence, most of the ancient Greeks regarded illness as a divine punishment and healing as a gift from their deities or gods.

By the fifth century B.C., the decline of civic religions opened a new path to community-oriented rites and festivals. This shift led to the growing popularity of divinities whose attributes could respond to personal feeling and needs (Risse, 1999). This new individualism found new deities - in response of those citizens in search of spiritual comfort. Among the deities, Asclepius, son of Apollo, is attributed as the god of medicine - a provider of healing and highly skilled doctor. In their quest for Asclepius help and meeting, they started building temples in his behalf.

Temples dedicated to Asclepius called Asclepieia or Asclepieion, were built mostly erected at favorable wooded sites, either near springs or near caves outside towns. These temples were highly standardized, usually consisting of rooms, halls, baths, etc.

In the Asclepieion, therapy was mainly magical - mystic in nature. Patients normally passed through two step procedure. The first stage was the physical and spiritual purity before approaching the divine. A new incoming patient or the sick one, passed through catharsis and purification stage - a series of cleansing baths and purgation, accompanied by a cleansing diet, which lasted several days. Then the supplicant was admitted into the sanctuary proper to participate in the Asclepian rites - a performance of prayers would take place. Prayers included invocation of the god, gift offering by the person (a sacrifice) and in the end the request itself. The second stage was the therapy. The therapy or the incubation was the process in which patients would spent a night in the temple and through their dreams they would receive proper treatment by Asclepius himself if they were lucky, or he would give them proper instructions how to treat their ailment. If Asclepius didn't visit them in their 
dreams, they would tell the dream to the priest or dream-interpreter so they would give the proper instructions depending of the type of the dream.

Among the first and most influential Ascleipieions is known the sanctuary at Epidaurus. It's complex, built in the fourth century B.C., includes a theater, katagogeion, Greek baths, gymnasium, baths, library, Asclepius's temple, etc. In figure 1 is shown the composite plan of central sanctuary area of the complex where the Athlon (2), Abaton (3) and the Temple of Asclepius (1) are shown.

Another influential healing sanctuary and medical school was the Ascleipieon on the island of Kos (Figure 2). It consists of three terraces: on the lowest level are located the main entrance of the Temple - a propylon (2), baths (4), springs, and a supposed medical school (6). The middle terrace holds the Temple of Apollo (11), the Altar (10), small Temple of Asclepius (14) and the Abaton (15). In the upper terrace, in the center axis of the sanctuary is located the Temple of Asclepius (17) surrounded by Greek stoa (18) and patients rooms (19).

The biggest healing complex found in Ancient Greece is the Asclepieon at Pergamon (Figure 3). It is made of building of different functions.

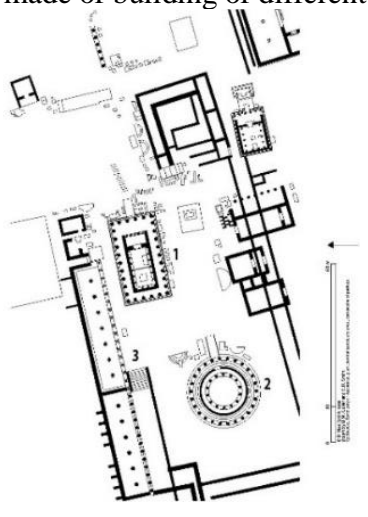

Figure 2. Asclepieion at Epidaurus $5^{\text {th }}$ century B.C. (Image courtesy: Tufts University)

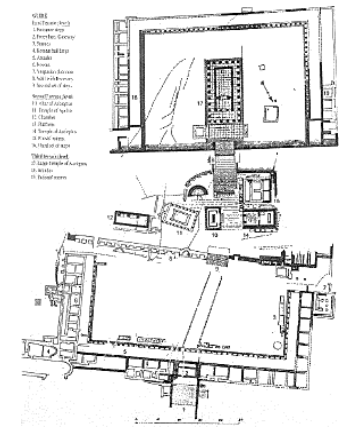

Figure 3. Asclepieion at Kos $4^{\text {th }}$ century B.C. (Image courtesy: M.S. Kiapokas 1999)

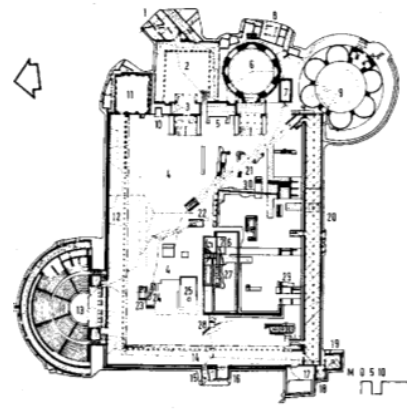

Figure 4. Asclepieion at Pergamon $4^{\text {th }}$ century B.C.(source:www.gottwein. de)

The entrance of the Temple - a Propylon is found in the east part of the complex (3) which leads to the central courtyard surrounded in the north, west and south side by a Stoa $(12,14,20)$. The Temple of Asclepius (6) is found in the eastern wing of the complex. Close to the Temple, a circular building (9) represents a treatment center linked with an underground tunnel with the central part of the complex where are located sleeping rooms, pools, baths and fountains.

\subsection{Roman Valetudinaria}

Another typological development in the spaces for healing and care can be observed in the Roman Empire. Similarly as in Ancient Greece, the Roman healthcare system was not a public duty and somehow failed to distinguish between rich and poor people for purposes of providing aid (Risse, 1999). Health issues seems to be personal issue i.e. healthcare remains an individual matter and not organized and systematized by the state.

Nevertheless, there was a responsibility of care within the estate administrators toward their own slaves. They created mostly small shelters for the rest and rehabilitation of their most valuable slaves. Instead of freely disposing of their dysfunctional slaves, landowners sought to treat and rehabilitate them in special shelters called valetudinaria. This kind of civil valetudinaria is supposed that have been located within estate administrator houses and imperial households (Risse, 1999). 
Book of Proceedings

International Conference on Architecture and Spatial Planning

The most significant development toward medical care can be seen in the military fortresses built mostly in the northern part of the Empire.

Dramatic changes occurred when Emperor Augusts (27 B.C. - 14 A.C.) established a new volunteer and professional army. To ensure high levels of recruitment, roman authorities reformed the military life and image into an attractive one. These reforms included regular salaries, bonuses, and opportunities to learn trading among others. In addition, soldier were able to receive medical care and treatment in the military valetudinaria. The military valetudinaria was consistent part of the permanent military fortresses (castra stativa) built by the Roman Empire in the northern frontier (Pitts \& Joseph, 1985).

Common to all valetudinariums is a rectangular design with rooms for patients (soldiers) arranged symmetrically on both sides of a middle corridor (Figure 4-7). The valetudinarium at Vetera (Figure 4) consists of seventy small wards of for beds each, physician quarters, a dispensary, a mortuary and isolation wards. Similar distribution of wards is found also in the valetudinarium in Vindonissa in Switzerland. With a capacity of 300 to 400 patients, the building has a symetric plan that discloses two large halls: one in the entrance and the other one in the courtyard (Figure 5).

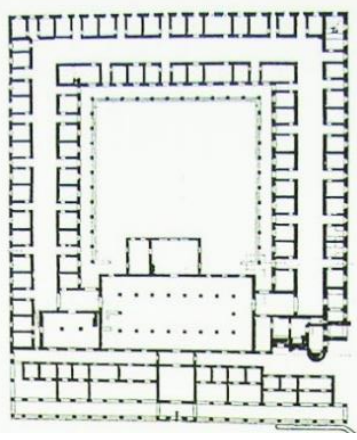

Figure 5. Valetudinarium in Vetera Xanten, Germany 54-68 A.C. (source:http://arachne.uni-koeln.de)

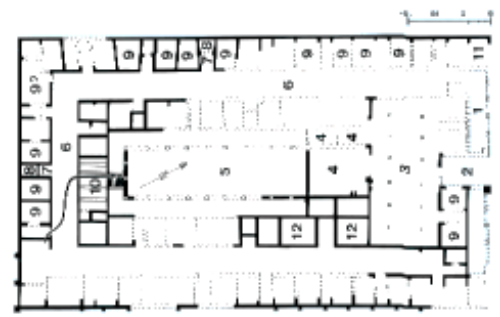

Figure 7. Valetudinarium at Novaesium Germany; 50 A.C.

Wilmanns. 2003)

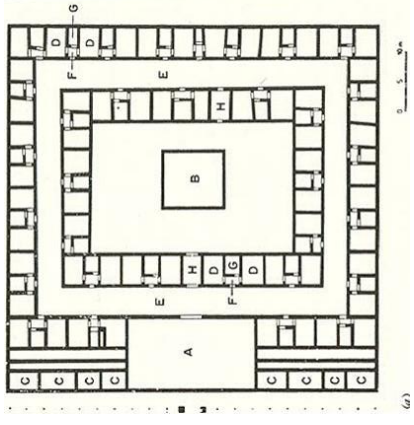

Figure 6. Valetudinarium in Vindonissa Switzerland, 100 A.C. (source:elearning.unifr.ch)

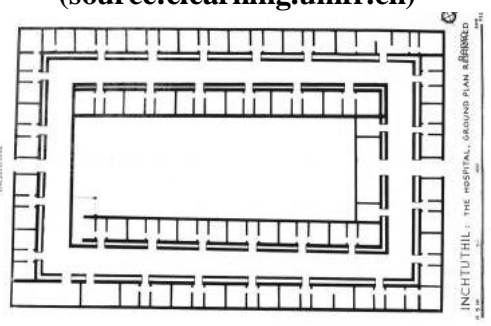

Figure 8. Valetudinarium in Inchutil, Great Britain (source: Pitts\&Joseph, 1985)

The valetudinaria provided to the patient the facilities, trained staff and rituals that contributed to both spiritual and physical healing of soldiers.

These two traditions - religious and military - will follow the hospital design development over the next two millennia's until the twentieth century. 


\subsection{Christian Xenodochi}

Unlike Roman utilitarian view of healing spaces, another way of treating the poor and the sick emerged in the eastern part of the Roman Empire. A new ideology started spreading with the teachings of Christ. His example of humanity in general and specifically the care for the sick, somehow charged his followers towards a new way of universal care and charity. The care for the sick was a sacred duty for each faithful together with the obligation and practice of hospitality. Located within the boundaries of the Roman Empire, this kind of humanity was practiced informally within persecuted Christian communities until the Council of Nicaea in the $4^{\text {th }}$ century when Christianity became official religion of the empire (Browne, 1912).

The newly formed Christian Church (after the Council in Nicaea, 325 A.C.), in their quest of fulfilling Christ's commands, urged and charged every bishopric and monastery to establish spaces for pilgrims, poor and sick people. This new spaces called 'Xenodochi' - a mixture between a guesthouse and a hospital - offered a wide range of services including healthcare ones (nosocomeion). Protection and social control of its occupants, togetherness services in open dormitories type environments and spiritual care of its inmates were the basic goals of the institution. Since it was adjacent to church and monastery, the institution was identified as a religious space. It consisted of rectangular complex with a central courtyard (atrium) with rooms arranged around its perimeter with a portico for circulation (Figure 8).

It is a matter of dispute the question of establishment of the first xenodochias and especially nosocomeions. Many agree that the Basilica of St. Basil at Caesarea in Cappadocia (369 A.C) was among the first to include a xenodochia. The example of St.Basil's was followed throughout the East.

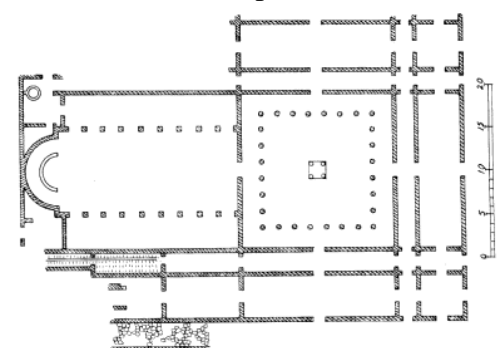

Figure 9. Xenodochium of Pammachius, 370-390 A.C. (Source: Lowrie, 1901)

Based on available evidences, it is difficult to find a consistent line of division between a xenon, a hostel providing shelter and food, and a nosokomeion, established for the healthcare purposes. Since they both developed adjunct with churches and monasteries, probably they shared common building plans. The Xenodochium of Pammachius reflects the potential example of early Christian xenodochias (Figure 8).

\section{Middle AGES}

\subsection{Medieval Christian Hospital}

Early Medieval Christian 'hospital' had a strong link in spirituality. Religion continued to be the dominant influence in the establishment of hospitals during the Middle-Ages. This was projected in the arrangement of the hospital building layout and architecture (Figure 9) as much as in the attention that was given to well-being of the patient's soul than to curing bodily ailments. In the early Middle 
Book of Proceedings

International Conference on Architecture and Spatial Planning

Ages (6th to 10th century), under the influence of the Benedictine $\operatorname{Order}^{52}$, an infirmary became an established part of every monastery.

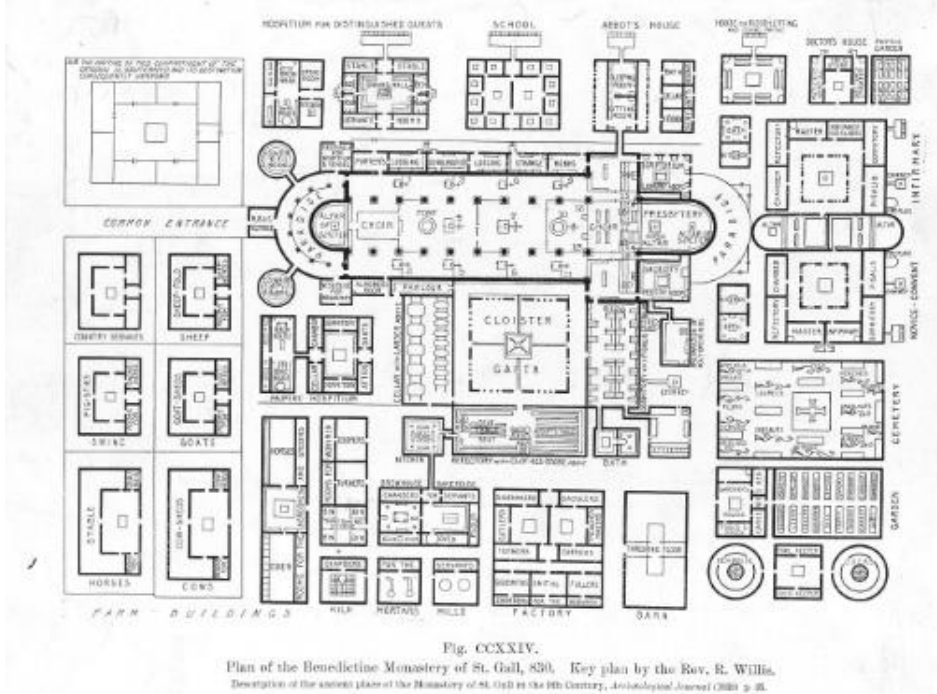

Figure 10. St. Gallen`s religious Complex, 820 A.C. (source: Courtauld Institute of Art)

A parchment plan of St. Gallen (Figure 9), was an ideal plan for the time that represented a complex of separated and clear functions around the church. Many monastic infirmaries were built during this time. Famous hospitals included St.John's hospital at Ephesus (610), Pantokrator in Constantinople (7th century), Hotel Dieu at Paris (651), Montpellier (738), Abbey of Saint Gall (820), St. Albans in England (794), St. Maria della Scala, Siena (898), and St. Bernard's Hospital in the Swiss Alps (962) (Cilliers \& Retief, 2002).

Other orders, similar to the Benedictian one included the order of the Bishop Chrodegang for the Carolignian Empire, the Synod of Aachen, military orders during crusades - order of St.John's of Jerusalem and that of Templars, the Augustinian order etc. (Pevsner, 1979).

\footnotetext{
${ }^{52}$ Catholic religious order initiated Saint Benedict of Nursia (480-543) which called for establishment of an infirmary in every monastery and placed the care for the sick above and before every other duty.
} 


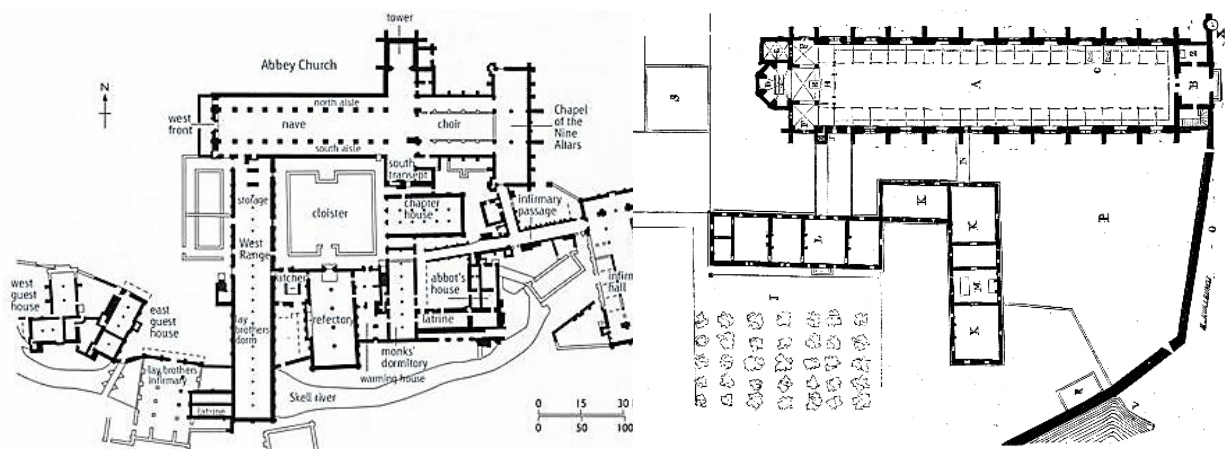

Figure 11. Fountains Abbey (1132),

Figure 12. Notre dame des Fontenilles Yorkshire (sorce: sacred-

(1293), Tonnerre (source:

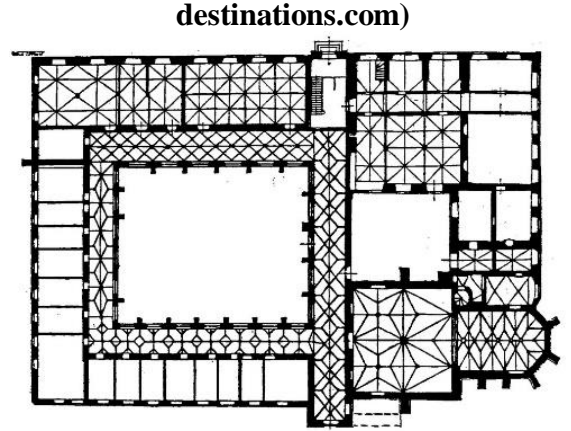

Figure 13. St. Nicholas Hospital (1447), Kues

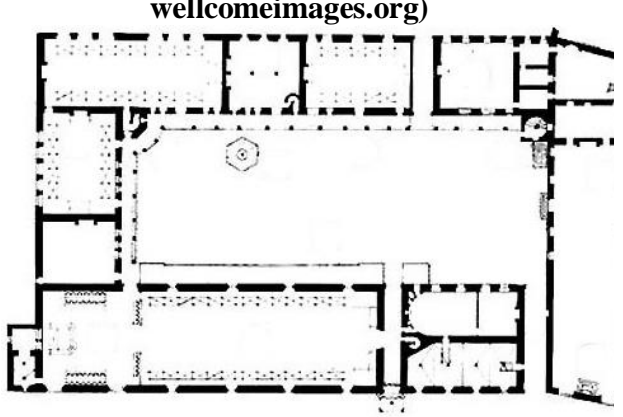

Figure 14. Hotel-Dieu (1443-51), Beaune
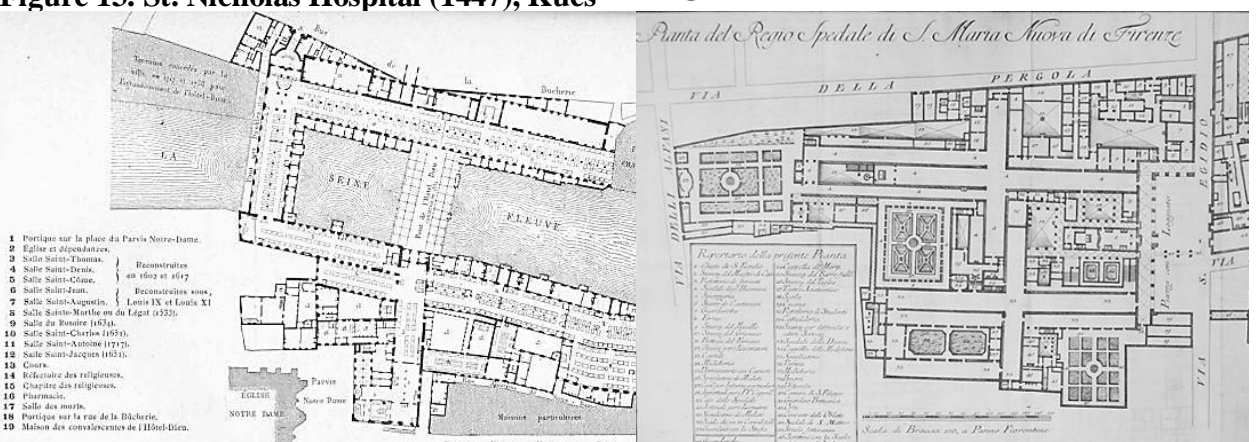

Figure 15. Hotel Dieu, Paris (651-

1772),Paris

(sorce:

http://stvincentimages.cstcis.cti.depaul.edu/ )

Figure 16. S.Maria Nuova (1286-1657), Florence (source: http://wwwext.comune.fi.it/)

During the high and late Middle-Ages, monastic infirmaries continued to expand churches (Figure 10), gradually expanding their medical services from monastic infirmaries to community ones (Figure $11,12,13)$, in both situations close and attached religious buildings. Public hospitals and specialized institutions were also opened, financed by city authorities, the church and private sources. In all cases, the religion constituted a dominant element of spatial configuration reflected both in the composition of the plan and interior - the sick should see and hear religious ceremonies from their beds. In general, they had large open wards with alter or chapel either in the middle or in the end of the space (Figure 10-13). 
Accordingly, new ways of treatments and care occurred during the high and late medieval Europe. Gradually, the medical works of the superior Arab physicians of the time, were translated into Latin and used as texts in medical schools established all over Europe ${ }^{53}$. Similarly to the Arab medicine, European Medieval physicians placed great emphasis on exercise, a healthy diet, and healthy living conditions. They often prescribed drugs, herbs, and hydrotherapy. Surgery, generally used only as a last resort (Risse, 1999).

\subsection{Islamic Bimaristans}

A radical change in hospital development emerged with the dawn and expansion of Islam. This new religion, not only strictly spiritual in nature, from the $8^{\text {th }}$ up to $15^{\text {th }}$ century formulated new kind of healthcare system and facilities by means of cultural, educational and scientific means. The emerged Islamic hospital, known as 'Bimaristan' or 'Maristan', embodies within its structure the ancient Greek idea of rational medicine, roman healthcare structures and Christian charitable institutions. During this time, the hospital earned not only a distinctive architectural form (Tabbaa, 2003) but also other characteristics which would contribute in the overall formulation: secular institution - run by the state officials and hired qualified physicians (by law, only qualified physicians were allowed to practice medicine) of all religious colors, serving to all its citizens for free without any regard to their race, religion, sex or social status; educational - serving as a medical school for educating and training medical students; separate wards - for both sexes and different diseases including wards for convalescent patients; separate nurses - female nurses taking care to female patients and contrariwise; medical records - keeping records for patients and their medical treatment (the first medical record in history); pharmacy - as a specialized subject within the hospital; baths and water supplies - for both patients and employees (Syed, 2003). The physicians of the Islamic world indeed did set up a concise healthcare system constituted of two principal goals: the welfare of their patient and teaching medicine to newly graduated physicians.

Initially, Islamic medicine was influenced by existing medical heritage, theories and practices of the time. They adopted mostly Greek, Roman, Chinese and Indian medical techniques, a knowledge that was preserved, systematized and further developed "by a community of Muslim and non-Muslim physicians speaking many languages across the vast area stretching from Spain, North Africa to India and the East" (Nawawi, 2002). Physicians like Al Razi ${ }^{54}$ (Rhazes), Al Zahrawi ${ }^{55}$ (Abulcasis) Ibn Sina $^{56}$ (Avicenna), Ibn Rushd (Averroes) ${ }^{57}$ Al Kindi, Ibn Al Nafis, Serapion (Syriac Christian) and many other scholars, departing from Galen's and Greek knowledge, made outstanding discoveries and genuine contributions in all aspects of medicine.

The patients were treated according to a clear scheme. It started with physiotherapy and diet, then drugs and if both of these treatments failed, surgery would be engaged. First two steps included exercises, water baths, dieting and proper nutrition, simple and compound drugs. If these

\footnotetext{
${ }^{53}$ Medichal school of Salerno (1121) was the first one in Europe

${ }^{54}$ Abu-Bakr Mohammaed Ibn-Zakaria Al-Razi (841-926) wrote books on refining scientific method and promoting experimentation and observation, medical ethics, nature of illness and human physiology.

55 Abū al-Qāsim Khalaf ibn al-'Abbās az-Zahrāwī (936-1013) wrote The Method of Medicine (Kitab al-Tasrif) - a 30 volume encyclopedia on medicine and surgery. Contains informations on wide variety of illnesses, injuries, medical conditions, treatments and surgical procedures.

${ }^{56}$ Abu-Ali Husayn lbn-Abdullah lbn-Sina (980-1037) was a Great Polymath who excelled in many academic fields including philosophy, theology, medicine and natural sciences. He wrote the famous "The Canon of Medicine" (al-Qānūn fī aț-Tỉibb) - a medical encyclopedia, a standard medical text at many medieval universities up to the late $17^{\text {th }}$ century.

${ }^{57}$ Abū l-Walīd Muhammad Ibn 'Ahmad Ibn Rushd (1126-1198) - a polymath. He wrote the book of "Generalities" (Kulliyat).
} 
FROM ASCLEPIUS TO OSPEDALE - THE EVOLUTION OF SPACE FOR HEALING FROM ANTIQUITY TO THE AGE OF ENLIGHTENMENT

conservative measures failed, surgery was undertaken (Syed, 2003). Also, music treatment was included for mentally ill patients.

Most of the hospitals of the medieval Islamic era were established in Cairo, Damascus, Granada, Seville, Cordoba and Baghdad. These hospitals were well organized with different wards for different types of illnesses, outpatient departments and theatres where medical students could attend lectures. These facilities were also provided with fountains to help wash themselves in line with cleanliness requirements of Islam (Nawawi, 2002).

The first bimaristans appeared during the Abbasids rule by Caliph Harun Al-Rashid in Baghdad (809 A.C) built under supervision of a Christian doctor named Ibn Bakhtishu. Six more hospitals were founded in the ninth and early tenth century in Baghdad, culminating with Al-Adudi hospital (978 A.C.) - a large hospital with twenty four physicians - destroyed by the Mongols in 1258. In Syria, following the Abbasid hospitals, Nur-al-Din did built several hospitals in Damascus (Figure 16-17), Aleppo (Figure 19), Hama, Raqqa and Harran. Furthermore, his ideas were continued by Saladin in other cities of the Caliphate such in Cairo, Alexandria, Jerusalem, Acre, and Ramla; followed by other rulers who did built hospitals on Anatolia, Egypt etc.

Bimaristans constituted an important urban construction and self-contained institution of Islamic cities. Compositionally, bimaristans are organized around a large courtyards - a garden or water fountain in its center. Most of the bimaristans, were entered through a single elaborated and controlled entrance and in general were set up by a cruciform four-iwans plan (lecture halls) (Figure 10-14). 
X

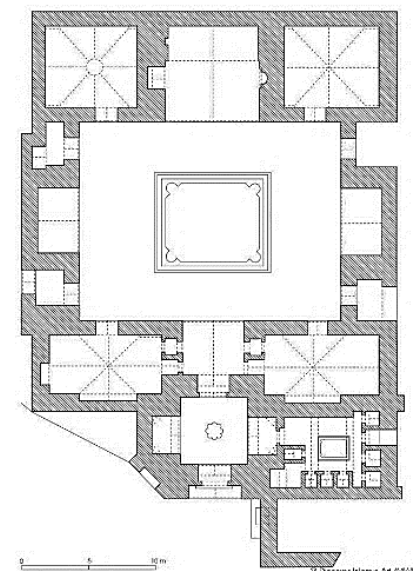

Figure 17.Bimaristan Nur al-Din (1154),

Damascus - Syria (source:

www.discoverislamicart.org)

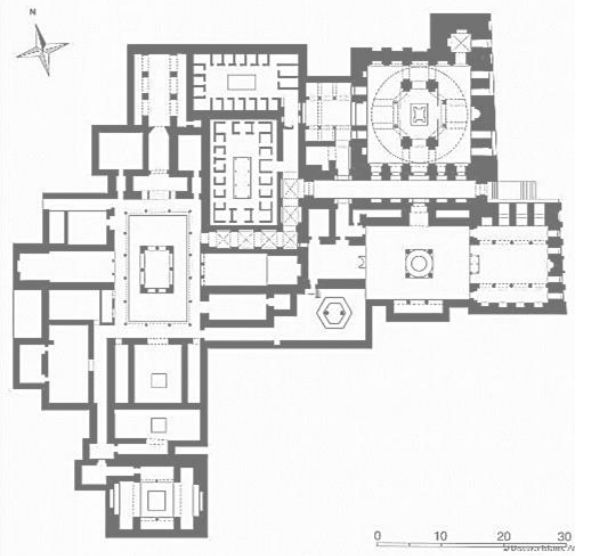

Figure 19. Mausoleum, Madras and Bimaristan of Sultan Qalawun (1284);

Cairo, Egypt (source:

www.discoverislamicart.org)

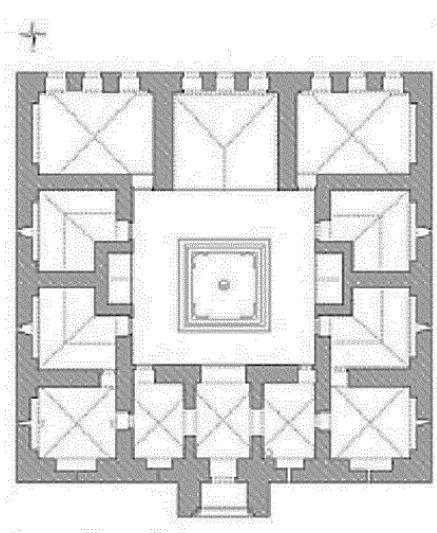

Figure 18. Bimaristan Qaymariyya (1248); Damascus, Syria (source: archnet.org)

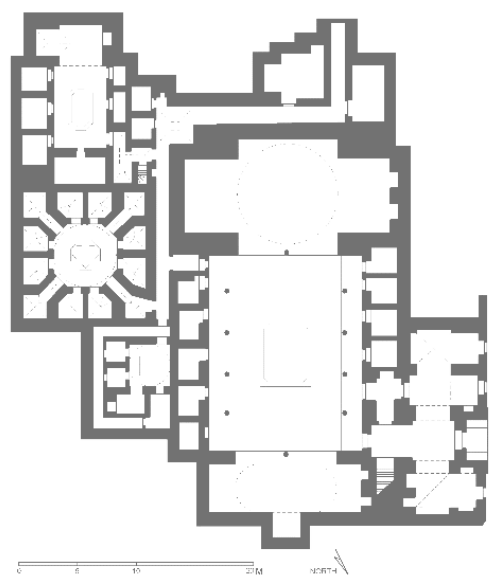

Figure 20. Bimaristan Al Arghuni (1354); Aleppo, Syria (source: archnet.org)

\section{Renesaince}

Similarly to Late Middle Ages, Renaissance also saw a reawakening of the spirit of scientific inquiry in medicine. The teachings of Galen, Aristotle, Arab physicians and other medical authorities of antiquity and other civilizations were no longer blindly accepted as dogma, but open to investigation and experimentation, and revision or deletion if necessary.

In convergence with the new developments in medicine, new architectural shapes and new type of building occurred during this time. Originally invented in Florence, the cross-shaped plan will 
become the most popular architectonic tool during the Renaissance up to the $17^{\text {th }}$ century. Santa Maria Nuova in Florence, dating from late $13^{\text {th }}$ century did undergo throughout many extensions: in $1334 \mathrm{a}$ men's department and later in 1660 women's department was added to the building - both cross shaped with an altar in the middle (Figure 15). The most important building of Italian Renaissance was the Ospedale Ca'Granda (Maggiore) in Milan - designed by Filarete in 1456 (Figure 21), it was the first building to use cross plan as deliberate architectural feature - a rectangular building with courtyards, consisted of two symmetrical cross-shaped wards with an altar in the center. Each of the wards was designed for sixty beds and it took more than three centuries to be constructed. Filarete's design's, became a framework for hospital design across Europe: many cross-shaped wards and hospitals in many different cities and countries emerged: in Italy - Pammatone in Genoa (Figure 21) - influenced by Florentine hospital S.M.Nuova, Mantua (1450-72); Great Hospital at Valletta in Malta; The Savoy in London (Figure 22); in Spain - Hospital Real in Santiago de Compostella (Figure 23), Santa Cruz in Toledo (1504-14), Hospital Real in Granada; also in France, Germany, South America were build similar hospitals, up to the $17^{\text {th }}$ century (Pevsner, 1979).

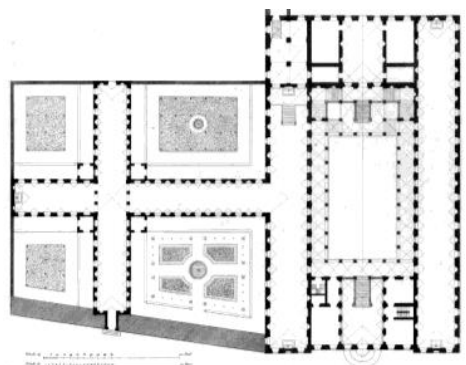

Figure 21. Pamattone (1422), Genoa (source: architettura.unige.it)

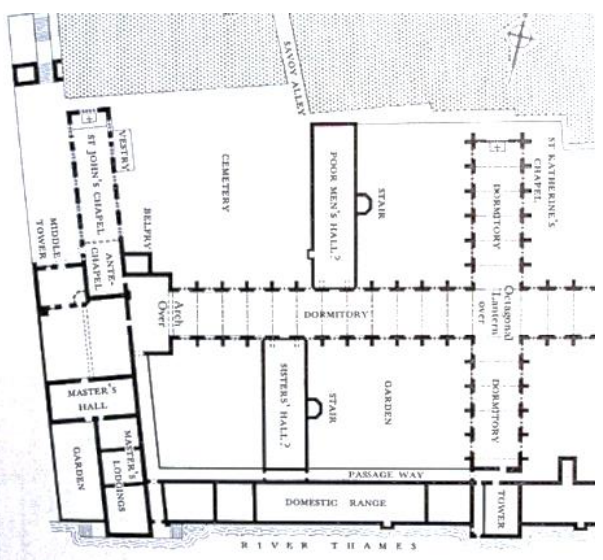

Figure 23. Savoy Hospital (1510-19), London (source:

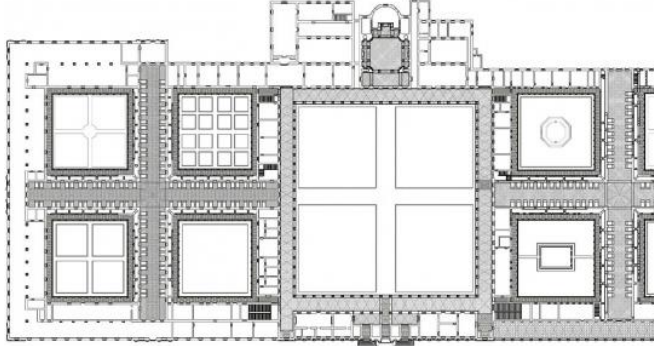

Figure 22. Ospedale Ca'Granda (Maggiore) (1456) Milan, Italy (source: http://caruso.arch.ethz.ch)

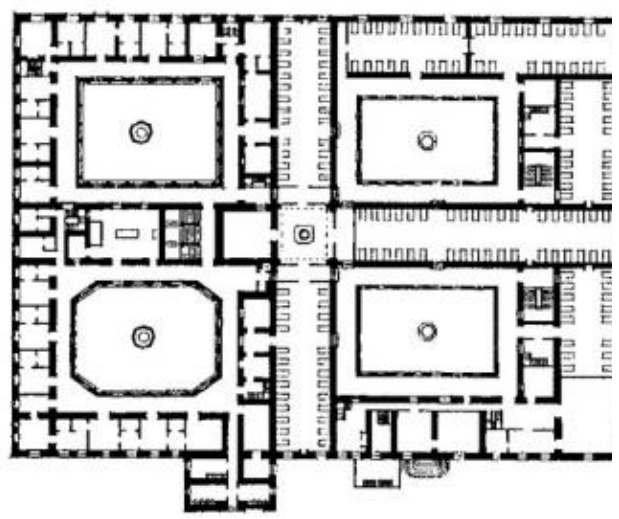

Figure 24. Hospital de Los Reyes (1501-15), Santiago de Compostella (source: quadraletics.wordpress.com) hleno.revues.org)

The use of the Greek cross, exploited for religious purposes as a distinct sign - a triumphal monument to thank God for his help in the struggle against their Muslim and Jewish counterparts - had many advantages: from the altar, four time more patients can be observed by nurses, and vice-versa, four time more patients can watch the altar for religious consolation; another advantage was the transversal section of the wards - for ventilation purposes. Whether this was the original intention of the designers, we don't know for sure. 
Book of Proceedings

International Conference on Architecture and Spatial Planning

The cross plan, will remain main architectural feature till the end of the $17^{\text {th }}$ century, when interest will focus in functional problems of design with the new advents in medical knowledge and discoveries. The healing spaces unlike the care for the patient will orient towards medical science and technology.

\section{Discussion}

According to many dictionaries, healthcare in a broader sense is defined as organized provision of medical care to individuals or a community with the intent of maintaining and improving "both physical and mental health" through medical services.

As elaborated in this paper, historically the physical and spiritual were two divided concepts of healing. The first concept employed by humans in their quest for bodily wellness was the mental one - spiritual. In the early developments of the healthcare spaces, the lack of rational medical knowledge during the classical and medieval ages, oriented healthcare services towards the supernatural powers and individual hope. Greeks and Romans saw illness as god's punishment and recovery as their gift. They developed organized facilities - temples, structured and composed according to the healing processes involved. Environment was a key element in their site selection. 
FROM ASCLEPIUS TO OSPEDALE - THE EVOLUTION OF SPACE FOR HEALING FROM ANTIQUITY TO THE AGE OF ENLIGHTENMENT

Table 4. Comparative analysis between main historical health-care oriented institutions (source: authors)

\begin{tabular}{|c|c|c|c|c|c|c|c|c|}
\hline & \multirow{2}{*}{$\begin{array}{l}\begin{array}{l}\text { Ascleipie } \\
\text { on }\end{array} \\
\begin{array}{l}\text { 5th up to 1st } \\
\text { century B.C }\end{array}\end{array}$} & \multirow{2}{*}{$\begin{array}{l}\begin{array}{l}\text { Valetudi } \\
\text { naria }\end{array} \\
\text { 1st up to } \\
\text { 3rd century }\end{array}$} & \multicolumn{3}{|l|}{ Xenodochi } & \multirow{2}{*}{$\begin{array}{l}\begin{array}{l}\text { Bimarist } \\
\text { an }\end{array} \\
\begin{array}{l}\text { 8th to 13th } \\
\text { century }\end{array}\end{array}$} & \multirow{2}{*}{$\begin{array}{l}\text { Ospedale } \\
\text { 14th up to } \\
\text { 17th } \\
\text { century }\end{array}$} \\
\hline \multirow[b]{3}{*}{$\begin{array}{l}\text { Characte } \\
\text { ristics of } \\
\text { the } \\
\text { hospitals }\end{array}$} & $\begin{array}{l}\text { Time } \\
\text { perio } \\
\text { d }\end{array}$ & & & $\begin{array}{l}\text { Early } \\
\text { Medieval } \\
\text { 3rd to 10th } \\
\text { century } \\
\end{array}$ & $\begin{array}{l}\text { High } \\
\text { Medieval } \\
\text { 10th to 13th }\end{array}$ & $\begin{array}{l}\text { Late } \\
\text { Medieval } \\
\text { 13th to 15th }\end{array}$ & & \\
\hline & \begin{tabular}{|c|}
$\begin{array}{c}\text { Sample } \\
\text { buildings }\end{array}$ \\
\end{tabular} & Kos & Vindonissa, & $\begin{array}{l}\text { Pammachiu } \\
\text { s, Porto }\end{array}$ & $\begin{array}{l}\text { Fountains } \\
\text { Abbey }\end{array}$ & $\begin{array}{l}\text { Fontenilles, } \\
\text { Tonnerre }\end{array}$ & $\begin{array}{l}\text { Qalawun, } \\
\text { Cairo }\end{array}$ & $\begin{array}{l}\text { Ca'Granda, } \\
\text { Milan }\end{array}$ \\
\hline & & & & & & & & \\
\hline \multicolumn{2}{|c|}{$\begin{array}{l}\text { Type of the } \\
\text { building }\end{array}$} & $\begin{array}{l}\text { mystical- } \\
\text { religious }\end{array}$ & military & $\begin{array}{l}\text { religious / } \\
\text { monastic }\end{array}$ & religious & public & public & public \\
\hline \multicolumn{2}{|c|}{ Financed by } & donations & roman empire & church & church & church & caliph & city authorities \\
\hline \multicolumn{2}{|c|}{$\begin{array}{l}\text { Location of the } \\
\text { building and } \\
\text { inclusiveness }\end{array}$} & $\begin{array}{l}\text { putside cities } \\
\text { part of complex }\end{array}$ & $\begin{array}{l}\text { within military } \\
\text { fortresses }\end{array}$ & $\begin{array}{l}\text { adjunct to } \\
\text { monasteries } \\
\text { and churches }\end{array}$ & $\begin{array}{l}\text { adjunct to } \\
\text { monasteries } \\
\text { and churches }\end{array}$ & self included & $\begin{array}{l}\text { self included } \\
\text { building within } \\
\text { city centres }\end{array}$ & within cities \\
\hline \multirow[t]{2}{*}{$\begin{array}{l}\text { Architec } \\
\text { tural } \\
\text { form }\end{array}$} & $\begin{array}{l}\text { struct } \\
\text { ure }\end{array}$ & $\begin{array}{l}\text { ndividual } \\
\text { buildings } \\
\text { distributed } \\
\text { around a main } \\
\text { courtyard and } \\
\text { main temple } \\
\end{array}$ & $\begin{array}{l}\text { solid building } \\
\text { with courtyard }\end{array}$ & $\begin{array}{l}\text { single solid } \\
\text { space }\end{array}$ & $\begin{array}{l}\text { complex of } \\
\text { individual } \\
\text { linked } \\
\text { buildings }\end{array}$ & solid & $\begin{array}{l}\text { articulated/soli } \\
\text { d building with } \\
\text { courtyard/s }\end{array}$ & $\begin{array}{l}\text { single solid } \\
\text { building with } \\
\text { courtyards }\end{array}$ \\
\hline & $\begin{array}{l}\text { genoty } \\
\text { pe }\end{array}$ & pavilion & with courtyard & solid & articulated & articulated & $\begin{array}{l}\text { articulated }+ \text { cou } \\
\text { rtyard }\end{array}$ & with courtyard \\
\hline \multirow{3}{*}{ Wards } & $\begin{array}{l}\text { Spaces } \\
\text { - Users }\end{array}$ & $\begin{array}{l}\text { big space for } \\
\text { multiple } \\
\text { mmates }\end{array}$ & $\begin{array}{l}\text { divided into } \\
\text { group of small } \\
\text { spaces up to 3-5 } \\
\text { patients }\end{array}$ & $\begin{array}{l}\text { single space for } \\
\text { multiple } \\
\text { inmates }\end{array}$ & $\begin{array}{l}\text { single space for } \\
\text { multiple } \\
\text { inmates }\end{array}$ & $\begin{array}{l}\text { single space for } \\
\text { multiple } \\
\text { patients }\end{array}$ & $\begin{array}{l}\text { multile single } \\
\text { spaces for } \\
\text { multiple } \\
\text { patients }\end{array}$ & $\begin{array}{l}\text { two single } \\
\text { spaces for } \\
\text { multiple users }\end{array}$ \\
\hline & $\begin{array}{l}\text { Diseas } \\
\text { se } \\
\text { divisio } \\
\text { n }\end{array}$ & & $y$ & no & no & no & yes & no \\
\hline & $\begin{array}{l}\text { Gende } \\
\mathbf{r} \\
\text { divisio } \\
\mathbf{n}\end{array}$ & & 4 & no & no & no & yes & yes \\
\hline \multirow{2}{*}{\multicolumn{2}{|c|}{$\begin{array}{l}\text { Dignosis and } \\
\text { Treatmant }\end{array}$}} & piritual & spiritual & ppiritual & $\begin{array}{l}\text { ppiritual, } \\
\text { physical }\end{array}$ & piritual & $\begin{array}{l}\text { physical, } \\
\text { ppiritual }\end{array}$ & $\begin{array}{l}\text { physical, } \\
\text { spiritual }\end{array}$ \\
\hline & & $\begin{array}{l}\text { rituals } \\
\text { therapeutic, } \\
\text { magigal mystic }\end{array}$ & $\begin{array}{l}\text { rituals,phyical } \\
\text { tretmennt, } \\
\text { rituals }\end{array}$ & $\begin{array}{l}\text { ritual, soul } \\
\text { cleansing }\end{array}$ & $\begin{array}{l}\text { humoral, } \\
\text { ritual, use of } \\
\text { drugs }\end{array}$ & $\begin{array}{l}\text { Rituals, drugs } \\
\text { and surgery }\end{array}$ & $\begin{array}{l}\text { physiotherapy, } \\
\text { drugs, surgery, } \\
\text { music }\end{array}$ & drugs, surgery \\
\hline \multicolumn{2}{|c|}{ Educational } & & no & l & no & no & yes & yes \\
\hline \multicolumn{2}{|c|}{$\begin{array}{l}\text { Main `medical } \\
\text { Staff }\end{array}$} & monks & trained staff & priests & $\begin{array}{l}\text { priests, lay- } \\
\text { physician }\end{array}$ & lay physician & $\begin{array}{l}\text { state qualified } \\
\text { physicians }\end{array}$ & $\begin{array}{l}\text { qualified } \\
\text { physicians }\end{array}$ \\
\hline \multicolumn{2}{|c|}{ Supportive staff } & practitioners & nurses & nuns & nuns & nursing staff & $\begin{array}{l}\text { female and } \\
\text { male nurses }\end{array}$ & $\begin{array}{l}\text { female and } \\
\text { male nurses }\end{array}$ \\
\hline
\end{tabular}

Christianity featured a new humanitarian view of care for the sick and poor but gradually monopolized the predominant monastic system of healthcare and contributed very little to the advancement of medical sciences and healing spaces. Their approach to healthcare was also spiritually oriented. A real change in healthcare services and spaces is seen during the Islamic "Golden Ages". Efforts to maintain and improve both physical and mental health are made by multi- 
Book of Proceedings

International Conference on Architecture and Spatial Planning

religious scientists and scholars during this time. It is this development that carried the flame of medical knowledge throughout the medieval "Dark Ages" to the dawn of the Renaissance in Europe. The structure of this paper was mainly focused on historical review of three basic principles that contribute in designing a hospital even in our times: cultural, medical and architectural features. Table 1 , summarizes a comparative analysis between the models with the most basic features that comprise a hospital. These characteristics include: type of the building, architectural form, wards, diagnosis and treatment, medical staff and supportive staff.

\section{Refereneces}

1. Al-Ghazal, S. K., 2007. The Origin of Bimaristans (Hospitals) in islamic Medical History, Manchester: FSTC Limited.

2. Browne, E. A., 1912. Early Christian and Byzantine Architecture. London: Adam and Charles Black.

3. Cilliers, L. \& Retief, F., 2002. The evolution of the hospital from antiquity to the end of the middle ages.. Curationis, 25(4), pp. 60-66.

4. Lowrie, W., 1901. Monuments of the early Church. New York: The Macmillan Company.

5. Nawawi, N. M., 2002. Islamic Perspective to Healthcare Facility Design. Berlin, UIA Public Health.

6. Pevsner, N., 1979. A history of building types. New Jersey: Priceton University Press.

7. Pitts, L. F. \& Joseph, J., 1985. Inchtuthil : the Roman legionary fortress excavations, 1952-65. London: Society for the Promotion of Roman Studies.

8. Prioreschi, P., 2001. A history of Medicine Vol. IV : Byzantine and Islamic Medicine. 1st ed. Omaha: Horatius Press.

9. Prodi, F. R. \& Stocchetti, A., 1990. L'architettura dell'ospedale. 1st ed. Firenze: Alinea Editrice.

10. Ragab, A., 2015. The Medieval Islamic Hospital: Medicine, Religion and Charity. New York: Cambridge University Press.

11. Retier, F. \& Cilliers, L., 2006. The evolution of hospitals from antiquity to the Renaissance. Acta Theologica, 26(2), pp. 213-232.

12. Risse, G. B., 1999. Mending Bodies, Saving Souls: A History of Hospitals. New York: Oxford University Press.

13. Syed, I. B., 2003. Efficient Hospitals: Islamic Medicine's Contribution to Modern Medicine. Journal of the International Society for the History of Islamic Medicine, 1(3), pp. 20-23.

14. Tabbaa, Y., 2003. The Functional Aspects of Medieval Islamic Hospitals. In: M. Ener, A. Singe \& M. Bonner, eds. Poverty and Charity in Middle Eastern Contexts. Albany: SUNY Press, pp. 95-119.

15. Wilmanns, J., 2003. Die ersten Krankenhäuser der Welt. Deutsches Ärzteblatt, October, 100(40), pp. A 2592-2597. 